\title{
CHANGES OF SPLEEN IN WISTAR RATS EXPOSED TO THERAPEUTIC DOSES OF DEXAMETHASONE AND MEDROXYPROGESTERONE ACETATE EVALUATED BY STEREOLOGICAL PARAMETERS
}

\author{
Elida Mitevska, Irena Kostadinova-Petrova, Nevena Kostovska
}

Institute of Medical, Experimental and Applied Histology and Embryology, Faculty of medicine, University "Ss Cyril and Methodius", Skopje, Republic of Macedonia

Corresponding Author: Elida Mitevska, Institute of MEP Histology and Embryology, Skopje, R. Macedonia; E-mail: elida_mitevska@yahoo.com

\begin{abstract}
The aim of our investigation was to evaluate the immunosuppressive effect of medroxyprogesterone acetate (MPA) determining the volume densities of the structural components of the spleen. The volume densities of the same structural components of spleen were determined after administration of dexamethasone too, in order to see whether the morphological changes induced by MPA are in the same line with the changes caused by dexamethasone.

60 female Wistar rats were divided into 5 groups. The control group of rats was administered physiological solution. The remaining, 4 experimental groups were administered: dexamethasone at a therapeutic daily dose of $0.6 \mathrm{mg} / \mathrm{kg}$ bw and maximal therapeutic dose of $3 \mathrm{mg} / \mathrm{kg}$ bw, and MPA at a therapeutic dose of $30 \mathrm{mg} / \mathrm{kg}$ bw and maximal therapeutic dose of $150 \mathrm{mg} / \mathrm{kg}$ bw. The drugs were applied intramuscularly for 7 days. Spleen paraffin sections were stained according to the methods: hematoxylin-eosin, Masson and Elastica van-Gieson. Stereological measurements were performed by using the Weibl's multipurpose test system (M-42).

The histological analyses of the structural components of the spleen in rats treated with dexamethasone and MPA have shown reduction of the white pulp and the marginal zone and an apparent decrease of the cellular density of the lymphocyte component of the pulp. The stereological analysis of the spleen showed significant decrease of the splenic pulp volume density and significant increase of the connective tissue volume density. Reducing the presence of splenic pulp was mainly due to the decrease in the volume density of all structural components of the white pulp. Changes were observed in all drug treated groups of rats.

Our results have shown that the MPA provoked changes suggested atrophy of the spleen lymphoid tissue. Although the atrophic changes of the spleen were significant after the application of both dexamethasone and MPA, the white pulp was significantly more sensitive substrate for dexamethasone than for the MPA.
\end{abstract}

Keywords: spleen, Wistar rats, stereological analysis, dexamethasone and medroxyprogesterone acetate

\section{Introduction}

One of the important ways for regulation of the immune response is an endocrine regulation which may be aimed at the stimulation or depression of the immune system. The central role in the immune-endocrine correlations occupy glucocorticoid hormones [1-4]. Some of the synthetic glucocorticoids express the immunomodulating effect, too. It is estimated that the effect of dexamethasone is 30 times stronger than the effect of the endogenous cortisol $[2,3]$.

All gestagens including medroxyprogesterone acetate (MPA) have structural similarities with the glucocorticoid hormones and 
many studies show their glucocorticoid action $[5,6]$. MPA is metylacetoxyprogesterone and its chemical formula is $6 \alpha$-metyl-acetoxy pregn4-en-3, 20 dion and is derived from 17 $\alpha$-hydroxyprogesterone by addition of the $6 \alpha$-acetate group. This is of particular importance as it is believed that the configuration of the steroid hormones is crucial for their immunosuppressive activity. The structural comparisons suggest that the C-19 and C-21 steroids that exhibit the most pronounced suppressive effect possess 4-en-3-one configuration in ring $\mathrm{A}$, and this suppressive activity increases with the C$17 \alpha$ substitution as in $17 \alpha$-hydroxiprogesterone [7]. Also, a prerequisite for the glucocorticoid activity of the steroid compounds is the presence of 6-alpha methyl group in its structure. This group is also contained in the MPA. Because of the structural similarities that exist between glucocorticoid and progestin hormones, authors have often conducted comparative studies comparing the two types of hormones or have made an attempt for hierarchical ordering in terms of their glucocorticoid and immunosuppressive effect $[8,9]$.

The experimental induction of the dexamethasone immunosuppression in rabbits demonstrated lymphopenia, eosinopenia, monocytopenia and basopenia in the peripheral blood [10]. The investigations on the larger lymphoid organs have reported that dexamethasone treatment causes apoptosis of thymocytes [11-13], but the effect on the lymphocytes from spleen, mesenteric and popliteal lymph nodes was less pronounced [10]. Some progestins as MPA do not cause atrophy, or other abnormalities of some large lymphoid organs (spleen) and the lymphoid tissue remains unchanged morphologically [14]. However, other authors observed that the therapeutic doses of MPA cause suppressing effects expressed in the lymphoid tissues and the organs [15-18]. Also, experimental studies conducted with contraceptive doses on mice show that the impact of the MPA is not limited to the genital system, but MPA has a significant impact on the immune system in terms of its weakening by increasing the possibility of spreading infections [19].

Despite the large number of physiological researches, quantitative morphological studies of the effect of MPA on the immune tissues and organs are missing.
Thus, the aim of our study was to determine and quantify eventual morphological changes of spleen after MPA treatment, and then to answer whether these changes are similar to the changes caused by dexamethasone treatment.

\section{Material and methods}

\section{Experimental animals}

Experimental animals are an important tool in the evaluation of the effect of drugs. As a laboratory model, laboratory rats have substantial equity in dimensions and genotype, and have low incidence of spontaneous disease. These features of the laboratory rats allow reliable comparisons between the experimental groups resulting in exceptional validity of the data obtained [20, 21]. That's why we chose the laboratory Wistar rats and used them as a model for assessment of the immunomodulatory effects of dexamethasone and MPA.

The experiment was performed with female rats, because MPA is commonly used in women for many indications especially for contraception and for the treatment of endometrial and breast cancer [22-24].

The age of the rats was 110 to 160 days. It is the age at which they reach sexual maturity and have normal production of endogenous steroid hormones from the sex glands. The age of rats corresponds to the mature woman between twenty to thirty years old. At that age the enzyme systems of rats are developed enough to be able to normally metabolize the test drugs.

The environmental factors that could influence the results of the experiment were strictly controlled. The experiment was conducted during all seasons that allow off stress caused by seasonal variations.

Rats were housed in a room without huge temperature variations and normal day-night rhythm of the natural light. They were fed with special food for rats and it hygienic drinking water was provided. Ammonia is the most common toxin found in air in the premises where rats are stored, so it was constantly disposed of with adequate ventilation.

The animal protocol was approved by the Ethical Committee for Animal Experiments of the Faculty of Medicine, Skopje, part of the University "Ss. Cyril and Methodius". 
Solutions and drugs used

in the experiment

The following solutions and drugs were used in the experiment:

- Saline (infusion solution) sterile apirogen, product of Hemofarm, Vrsac, Serbia;

- Dexamethasone, vials with concentration $4 \mathrm{mg} / \mathrm{ml}$, manufactured by Krka, Novo Mesto, Slovenia;

- Dugen forte, vials containing $500 \mathrm{mg}$ MPA/3.3 $\mathrm{ml}$ (aqueous suspension of MPA in a concentration of $150 \mathrm{mg} / \mathrm{ml}$ ) manufactured by Hemofarm, Vrsac, Serbia;

- Ether (diethyl ether), molar mass 74.12 $\mathrm{g} / \mathrm{mol}$, product of Merck, Germany.

\section{Treatment of rats}

The experiment included a total number of 60 rats divided into 5 groups, each one consisting of 12 animals.

- The control group of rats was given physiological solution.

- The first experimental group was administered dexamethasone at a therapeutic dose of $0.6 \mathrm{mg} / \mathrm{kg} \mathrm{bw}$.

- The second experimental group was administered dexamethasone at a maximal therapeutic dose of $3 \mathrm{mg} / \mathrm{kg}$ bw.

- The third experimental group was administered MPA at a therapeutic dose of $30 \mathrm{mg} / \mathrm{kg}$ bw.

- The fourth experimental group was administered MPA at a maximal therapeutic dose of $150 \mathrm{mg} / \mathrm{kg}$ bw.

The therapeutic doses of dexamethasone and MPA correspond to the doses that have been usually applied in therapeutic purposes and the maximal therapeutic doses are the highest doses that have been applied for treatment.

The doses of dexamethasone and MPA which were used in our experiment were adapted specifically for the rats. Also, the therapeutic dose dexamethasone is equivalent to the therapeutic dose MPA, and the maximal therapeutic dose dexamethasone is equivalent to the maximal therapeutic dose MPA.

The required concentrations of dexamethasone and MPA were obtained by diluting the products of the drugs with saline.

The method of application of drugs in rats was intramuscular, determined by the usual method of application in humans. The saline and drugs were applied with a volume of 0.1 $\mathrm{ml}$ every day for 7 days.

\section{Sacrifice of rats}

The animals were sacrificed 24 hours after application of the final injection of saline or drug after anesthesia with ether. After the opening, the anterior abdominal wall spleens were removed with blunt tweezers and measured with precision electronic scales.

\section{Histological methods}

The removed spleens were fixed in buffered $10 \%$ formalin solution for 24 hours. After the fixation, other procedures of histological paraffin technique were performed on tissue samples. The spleen paraffin sections with thickness of $4 \mu \mathrm{m}$ were stained by routine hematoxylin-eosin stain, as well as the special stains Elastica van Gieson and Masson's trichrome stain, in order to precisely visualize both the parenchyma and connective tissue enabling qualitative histological analysis and exact stereological measurements.

The quantitative stereological method allows three-dimensional interpretation of the flat surfaces (intersection points) assisted by the criteria of geometrical probability [25, 26].

The stereological measurements were done using light microscope (Olympus model CX21FS1, manufactured by Olympus Corporation, Tokyo, Japan) with built-in Weibel's multipurpose test system M-42 which has 42 test points. The volume density of the investigated tissue phases $\left(\mathrm{V}_{\mathrm{vf}}\right)$ was determined using the following formula:

$$
\mathrm{V}_{\mathrm{vf}}=\mathrm{P}_{\mathrm{f}} / \mathrm{P}_{\mathrm{t}}
$$

where $\mathrm{P}_{\mathrm{f}}$ is the number of points that coincide with the examined phase and $\mathrm{P}_{t}$ is the number of points of the test system.

$\mathrm{V}_{\mathrm{vf}}$ is a relative stereological value which shows the size of the total space that belongs to the examined phase. If the obtained value is multiplied with 100, the result gives the percent of the examined phase per space unit. The number of reference fields where we performed the stereological measurements was at least 100 , which means that at least 4,200 test points for each spleen were determined.

The quantitative data obtained with the stereological analysis were statistically analy- 
zed with the Student's t-test (statistical significance 0.05 level).

\section{Results}

The qualitative histological analysis of the spleen samples in the control group of rats has shown a thin but dense fibroelastic outer capsule from which short trabeculae extend into the parenchyma. These supporting tissues (capsule and trabeculae) included a marked presence of smooth muscle cells and collagen fibers scantily represented (Fig. 1 a).

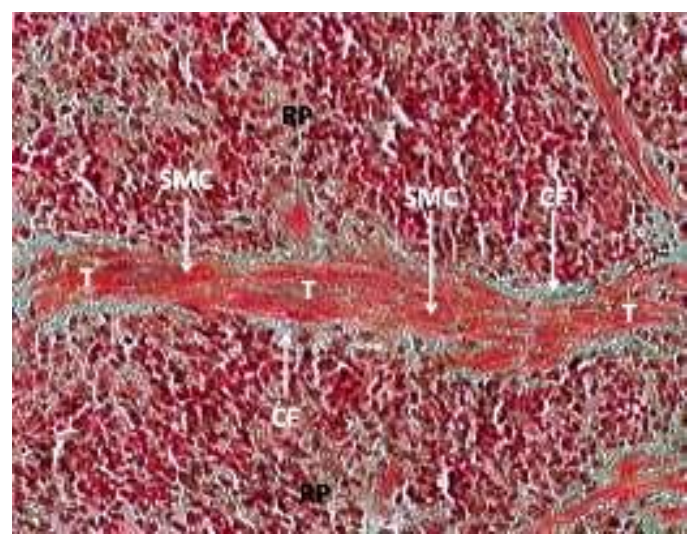

a) Control group

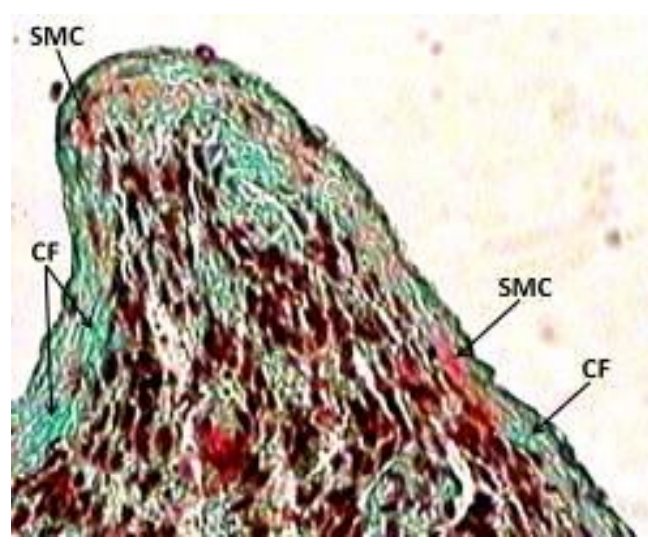

b) Dexamethasone: $0.6 \mathrm{mg} / \mathrm{kg} \mathrm{bw}$

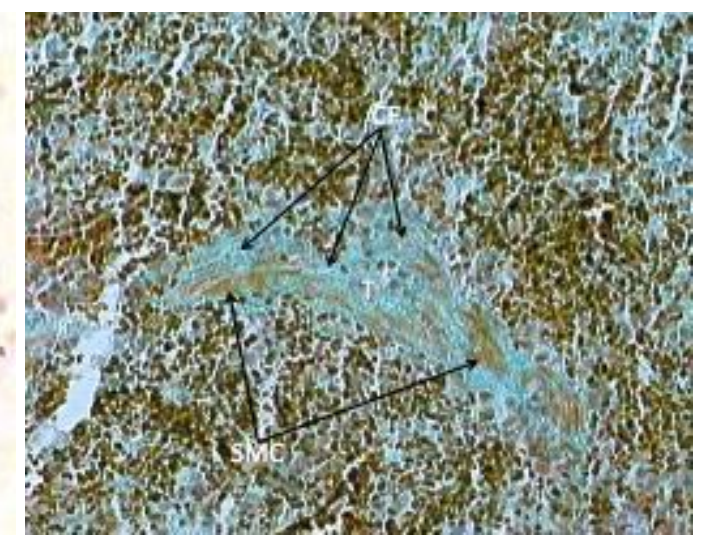

c) Dexamethasone: $3 \mathrm{mg} / \mathrm{kg} \mathrm{bw}$

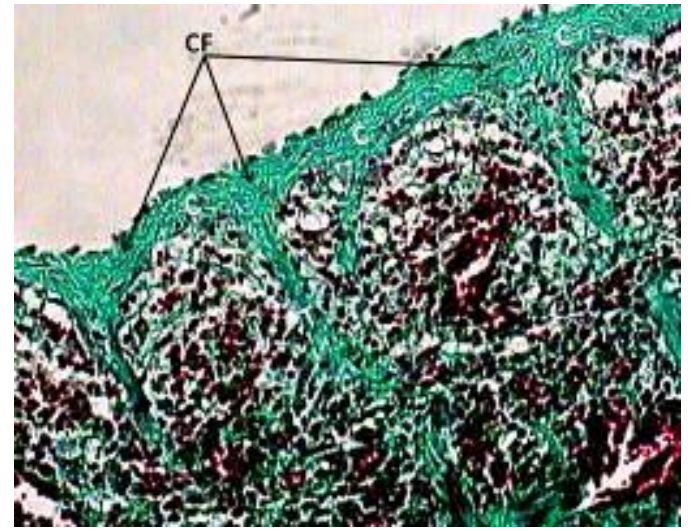

d) MPA: $30 \mathrm{mg} / \mathrm{kg} \mathrm{bw}$

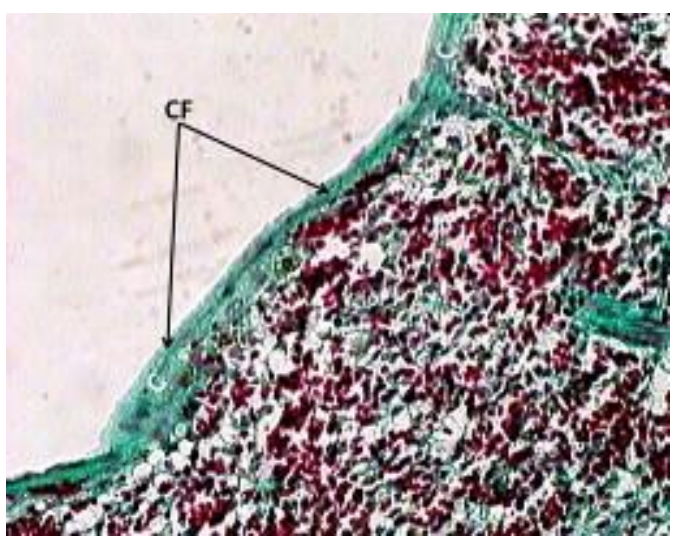

e) $M P A: 150 \mathrm{mg} / \mathrm{kg} \mathrm{bw}$

Fig. 1 - Presence of smooth muscle cells $(S M C)$ and collagen fibers $(C F)$ in the spleen capsule $(C)$ and trabeculae $(T)$

a) Expressed presence of SMS and less represented CF in the spleen trabeculae; Masson, $10 \times 20$

b) Rarely represented SMC and excessive presence of CF; Masson, $10 \times 20$

c) Rarely represented SMC and excessive presence of CF; Masson, $10 \times 20$

d) Complete absence of SMC; Masson, $10 \times 20$

e) Complete absence of SMC; Masson, $10 \times 20$ 
The splenic white pulp in the control group of rats was characterized by clearly differentiated $\mathrm{T}$ cell areas surrounding the central arteries, forming periarteriolar lymphoid sheath (PALS). Also, there was a clear differentiation of the lymphoid follicles. Many of the follicles exhibit germinal centers with present mitoses.
At the follicle periphery there was a mantle zone beyond which there was a broader marginal zone. The marginal sinus was also clearly differentiated. The boundary between the white and the red pulp was well expressed. The ratio of presence of white and red splenic pulp was common (Fig. 2 a).

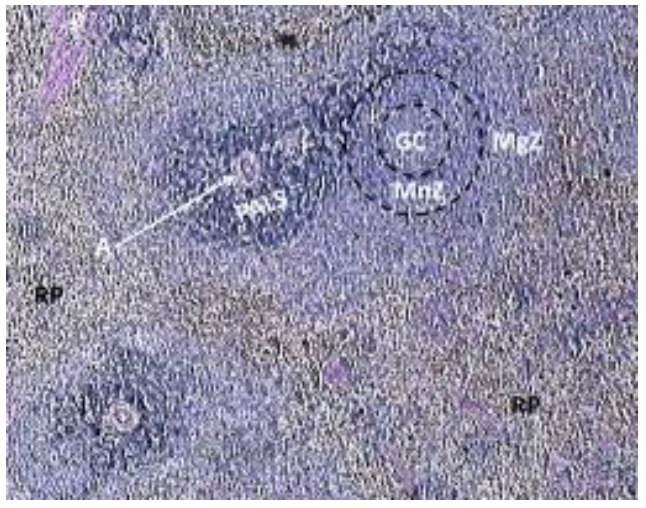

a) Control group

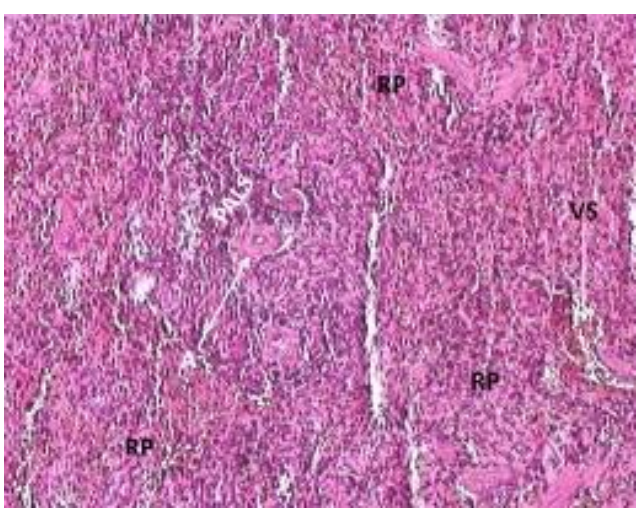

b) Dexamethasone: $0.6 \mathrm{mg} / \mathrm{kg} \mathrm{bw}$

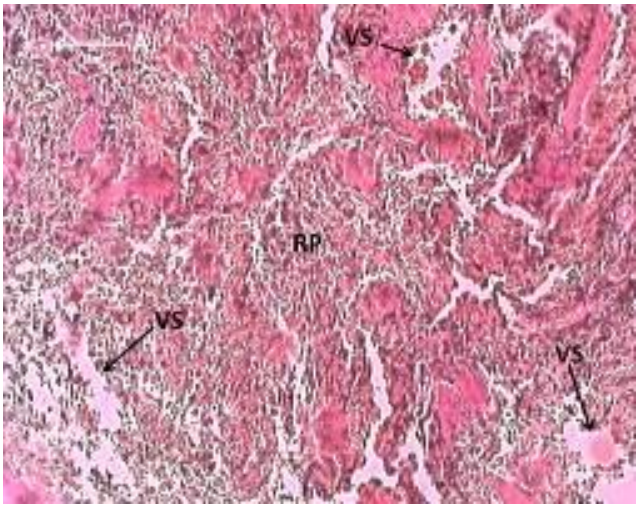

d) MPA: $30 \mathrm{mg} / \mathrm{kg} \mathrm{bw}$

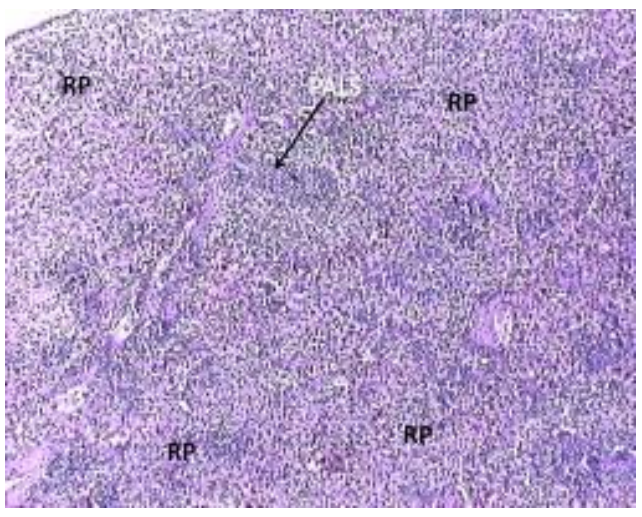

c) Dexamethasone: $3 \mathrm{mg} / \mathrm{kg} \mathrm{bw}$

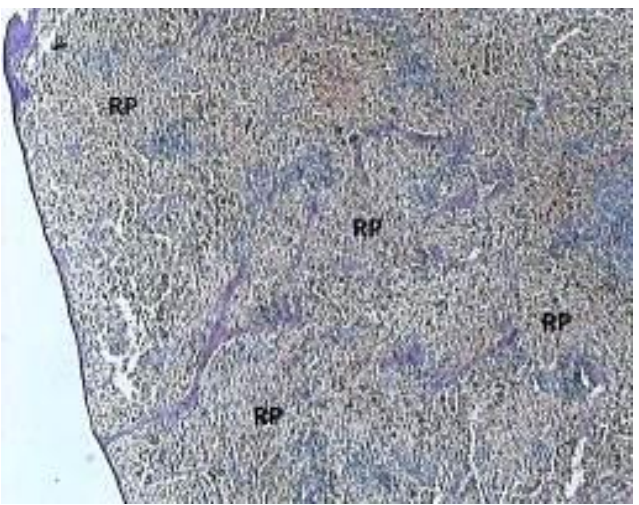

e) MPA: $150 \mathrm{mg} / \mathrm{kg} \mathrm{bw}$

Fig. 2 - Histological structure of the spleen: central arteriole (A), periarteriolar lymphoid sheath (PALS), germinal centre $(G C)$ and mantle zone $(M n Z)$ of the lymph follicle, marginal zone (MgZ), red pulp (RP)

a) Normal histological structure of the spleen with clearly differentiated compartments of white and red pulp; Elastica van Gieson, $10 \times 4$

b) Dominance of red pulp; Hematoxylin-eosin, $10 \times 10$

c) Dominance of red pulp; PAS, $10 \times 4$

d) Dominance of red pulp and severe venous sinuses; Elastica van Gieson, $10 \times 10$

e) Dominance of red pulp; Elastica van Gieson, $10 \times 4$ 
The histological analysis in the drug treated groups of rats showed that the application of dexamethasone and MPA, provoked very similar morphological changes of the spleen tissue, therefore qualitative histological analysis of all experimental groups will be presented together with the emphasis on the properties specific to individual groups.

After dexamethasone and MPA administration in therapeutic and maximal therapeutic doses it was observed that the surface of the spleen (and capsule) was picked and trabeculae had irregular deployment. As for the structural components of the capsule and trabeculae smooth muscle cells reduction and collagen fibers dominance was noticed in all experimental groups when compared with the control group of rats (Fig. 1).

The qualitative histological analysis of the spleen parenchyma showed irregular, chaotic schedule and unclear differentiation of the spleen tissue compartments. The lymph follicles were rarely represented and had smaller dimensions. They were in a phase of involution meaning that they have poorly formed (inactive) germinal centers in which mitoses can be rarely seen. In the majority of the lymph follicles the germinal centers did not exist. Complete absence of germinal centers in lymph follicles in all samples of spleen tissue was observed only after the administration of dexamethasone at a maximal therapeutic dose of $3 \mathrm{mg} / \mathrm{kg} \mathrm{bw}$. As for the density of the immunocompetent cells, a reduced density of the lymphocytes in the white pulp was observed and, also, an appearance of lymphocyte depletion. At some places the white pulp of the spleen was characterized by disruption of its normal cytoarchitecture. A loss of the clear boundary between the individual components that make the white pulp was noticed. The marginal zone was reduced in thickness. The red pulp was represented by narrowed cords of cells and broad venous sinusoids between them. The presence of white and red pulp was subject to change as manifested by the reduced presence of the white pulp in favor of the red pulp (Fig. 2).

The statistical analysis of the spleen weight showed a significant reduction in rats treated with therapeutic and maximal therapeutic dose of dexamethasone $(p<0.01)$ and the maximal therapeutic dose of MPA $(p<0.05)$ when compared with the control group. The administration of the therapeutic dose of MPA led to some reduction in the spleen weight, but it was not statistically significant (Table 1 and Table 2).

Table 1

Spleen weight after dexamethasone treatment of rats at a therapeutic dose (a), and maximal therapeutic dose (b)

a)

b)

\begin{tabular}{|c|c|c|c|c|c|c|}
\hline & & $\begin{array}{c}\text { Control group } \\
\bar{x} \pm \mathrm{SD}\end{array}$ & $\begin{array}{c}\text { Dex }(0,6 \mathrm{mg} / \mathrm{kg} \mathrm{bw}) \\
\overline{\boldsymbol{x}} \pm \mathrm{SD}\end{array}$ & t-value & $\mathrm{df}$ & $\mathrm{p}$ \\
\hline Variable & $\mathrm{n}$ & $263.75 \pm 90,73$ & 3.40 & 22 & $<0.01$ \\
\hline
\end{tabular}

\begin{tabular}{|c|c|c|c|c|c|c|}
\hline Variable & $\mathrm{n}$ & $\begin{array}{c}\text { Control group } \\
\bar{x} \pm \text { SD }\end{array}$ & $\begin{array}{c}\operatorname{Dex}\left(\frac{3}{x} \pm \mathrm{mg} / \mathrm{kg} \text { bw }\right) \\
\pm \mathrm{SD}\end{array}$ & t-value & $\mathrm{df}$ & $\mathrm{p}$ \\
\hline Spleen weight (mg) & 12 & $393.75 \pm 96.67$ & $273.17 \pm 95.85$ & 3.07 & 22 & $<0.01$ \\
\hline
\end{tabular}

$\bar{x}$ - Mean value of the variable; SD - standard deviation; $\mathrm{df}$ - degree of freedom

Table 2

a)

Spleen weight after MPA treatment of rats at a therapeutic dose (a), and maximal therapeutic dose (b)

\begin{tabular}{|c|c|c|c|c|c|c|}
\hline Variable & $\mathrm{n}$ & Control group & MPA $(30 \mathrm{mg} / \mathrm{kg} \mathrm{bw})$ & $\mathrm{t}$-value & $\mathrm{df}$ & $\mathrm{p}$ \\
\hline Spleen weight $(\mathrm{mg})$ & 12 & $393.75 \pm 96.67$ & $353.83 \pm 132,66$ & 0.84 & 22 & n.s. \\
\hline
\end{tabular}

b)

\begin{tabular}{|c|c|c|c|c|c|c|}
\hline Variable & $\mathrm{n}$ & Control group & MPA $(150 \mathrm{mg} / \mathrm{kg} \mathrm{bw})$ & $\mathrm{t}$-value & $\mathrm{df}$ & $\mathrm{p}$ \\
\hline Spleen weight $(\mathrm{mg})$ & 12 & $393.75 \pm 96.67$ & $308.33 \pm 108.60$ & 2.04 & 22 & $<0.05$ \\
\hline
\end{tabular}

$\bar{x}$ - Mean value of the variable; SD - standard deviation; df - degree of freedom

The quantitative stereological analysis of the spleen tissue showed significant decrease of the splenic pulp volume density $(\mathrm{p}<0.01)$ and significant increase of the connective tissue volume density $(p<0.01)$ in all groups of drug treated rats when compared with the control 
group. Reducing the presence of the splenic pulp is mainly due to the decrease in volume density of all structural components of the white pulp (PALS, lymph follicles and its` germinal centers and mantle zones). The volume density of the marginal zone was also reduced in all groups of drug treated rats $(\mathrm{p}<0.01)$. Contrary to the volume density of the white pulp and the marginal zone, the volume density of the red pulp was significantly increased in all groups of drug treated rats $(\mathrm{p}<0.01)$; (Table 3 and Table 4).

Table 3

Volume density $\left(\% / \mathrm{mm}^{3}\right.$ tissue) of the tested structural components of the splenic tissue after dexamethasone treatment of the rats at a therapeutic dose (a), and maximal therapeutic dose (b)

a)

\begin{tabular}{|c|c|c|c|c|c|c|}
\hline $\begin{array}{c}\text { Volume density } \\
\left(\% / \mathrm{mm}^{3}\right)\end{array}$ & $\mathrm{n}$ & $\begin{array}{c}\text { Control group } \\
\bar{x} \pm \mathrm{SD}\end{array}$ & $\begin{array}{c}\text { Dex }(0,6 \mathrm{mg} / \mathrm{kg} \text { bw }) \\
\overline{\boldsymbol{X}} \pm \mathrm{SD}\end{array}$ & t-value & $\mathrm{df}$ & $\mathrm{p}$ \\
\hline Pulp & 12 & $96.91 \pm 0.93$ & $94.20 \pm 0.90$ & 7.23 & 22 & $<0.01$ \\
\hline Connective tissue & 12 & $3.09 \pm 0.93$ & $5.80 \pm 0.90$ & -7.23 & 22 & $<0.01$ \\
\hline White pulp & 12 & $16.60 \pm 1.14$ & $5.21 \pm 1.09$ & 24.94 & 22 & $<0.01$ \\
\hline Red pulp & 12 & $60.04 \pm 2.79$ & $82.32 \pm 2.16$ & -21.83 & 22 & $<0.01$ \\
\hline PALS & 12 & $10.51 \pm 1.24$ & $4.36 \pm 0.86$ & 13.99 & 22 & $<0.01$ \\
\hline Lymph follicles & 12 & $6.09 \pm 0.82$ & $0.85 \pm 0.48$ & 18.96 & 22 & $<0.01$ \\
\hline Germinal centers & 12 & $1.11 \pm 0.23$ & $0.04 \pm 0.06$ & 14.86 & 22 & $<0.01$ \\
\hline Mantle zone & 12 & $4.98 \pm 0.63$ & $0.81 \pm 0.43$ & 18.64 & 22 & $<0.01$ \\
\hline Marginal zone & 12 & $20.20 \pm 1.92$ & $6.67 \pm 1.01$ & 21.49 & 22 & $<0.01$ \\
\hline
\end{tabular}

b)

\begin{tabular}{|c|c|c|c|c|c|c|}
\hline $\begin{array}{c}\text { Volume density } \\
\left(\% / \mathrm{mm}^{3}\right)\end{array}$ & $\mathrm{n}$ & $\begin{array}{c}\text { Control group } \\
\overline{\boldsymbol{x}} \pm \mathrm{SD}\end{array}$ & $\begin{array}{c}\text { Dex }\left(\frac{3}{\bar{x}} \mathrm{mg} / \mathrm{kg} \text { bw }\right) \\
\mathrm{SD}\end{array}$ & $\mathrm{t}$-value & $\mathrm{df}$ & $\mathrm{p}$ \\
\hline Pulp & 12 & $96.91 \pm 0.93$ & $94.06 \pm 1.27$ & 6.27 & 22 & $<0.01$ \\
\hline Connective tissue & 12 & $3.09 \pm 0.93$ & $5.94 \pm 1.27$ & -6.27 & 22 & $<0.01$ \\
\hline White pulp & 12 & $16.60 \pm 1.14$ & $1.85 \pm 0.52$ & 40.61 & 22 & $<0.01$ \\
\hline Red pulp & 12 & $60.04 \pm 2.79$ & $89.61 \pm 2.55$ & -27.02 & 22 & $<0.01$ \\
\hline PALS & 12 & $10.51 \pm 1.24$ & $1.54 \pm 0.43$ & 23.47 & 22 & $<0.01$ \\
\hline Lymph follicles & 12 & $6.09 \pm 0.82$ & $0.30 \pm 0.23$ & 23.28 & 22 & $<0.01$ \\
\hline Germinal centers & 12 & $1.11 \pm 0.23$ & $0.00 \pm 0.00$ & 16.06 & 22 & $<0.01$ \\
\hline Mantle zone & 12 & $4.98 \pm 0.63$ & $0.30 \pm 0.23$ & 23.77 & 22 & $<0.01$ \\
\hline Marginal zone & 12 & $20.20 \pm 1.92$ & $2.61 \pm 1.30$ & 26.20 & 22 & $<0.01$ \\
\hline
\end{tabular}

$\bar{x}$ - Mean value of variables; SD - standard deviation; df - degree of freedom

Table 4

Volume density $\left(\% / \mathrm{mm}^{3}\right.$ tissue $)$ of the tested structural components of the splenic tissue after MPA treatment of the rats at a therapeutic dose (a), and maximal therapeutic dose (b)

a)

\begin{tabular}{|c|c|c|c|c|c|c|}
\hline $\begin{array}{c}\text { Volume density } \\
\left(\% / \mathrm{mm}^{3}\right)\end{array}$ & $\mathrm{n}$ & $\begin{array}{c}\text { Control group } \\
\bar{x} \pm \text { SD }\end{array}$ & $\begin{array}{c}\text { MPA }(30 \mathrm{mg} / \mathrm{kg} \mathrm{bw}) \\
\bar{x} \pm \mathrm{SD}\end{array}$ & t-value & df & $\mathrm{p}$ \\
\hline Pulp & 12 & $96.91 \pm 0.93$ & $93.92 \pm 1.00$ & 7.54 & 22 & $<0.01$ \\
\hline Connective tissue & 12 & $3.09 \pm 0.93$ & $6.07 \pm 1.01$ & -7.55 & 22 & $<0.01$ \\
\hline White pulp & 12 & $16.60 \pm 1.14$ & $6.55 \pm 1.24$ & 20.61 & 22 & $<0.01$ \\
\hline Red pulp & 12 & $60.04 \pm 2.79$ & $79.69 \pm 2.43$ & -18.34 & 22 & $<0.01$ \\
\hline PALS & 12 & $10.51 \pm 1.24$ & $4.38 \pm 0.77$ & 14.44 & 22 & $<0.01$ \\
\hline Lymph follicles & 12 & $6.09 \pm 0.82$ & $2.18 \pm 0.63$ & 13.01 & 22 & $<0.01$ \\
\hline Germinal centers & 12 & $1.11 \pm 0.23$ & $0.19 \pm 0.12$ & 11.88 & 22 & $<0.01$ \\
\hline Mantle zone & 12 & $4.98 \pm 0.63$ & $1.99 \pm 0.53$ & 12.39 & 22 & $<0.01$ \\
\hline Marginal zone & 12 & $20.20 \pm 1.92$ & $7.66 \pm 1.51$ & 17.74 & 22 & $<0.01$ \\
\hline
\end{tabular}

b)

\begin{tabular}{|c|c|c|c|c|c|c|}
\hline $\begin{array}{c}\text { Volume density } \\
\left(\% / \mathrm{mm}^{3}\right)\end{array}$ & $\mathrm{n}$ & $\begin{array}{c}\text { Control group } \\
\overline{\boldsymbol{x}} \pm \mathrm{SD}\end{array}$ & $\begin{array}{c}\text { MPA }(150 \mathrm{mg} / \mathrm{kg} \mathrm{bw}) \\
\overline{\boldsymbol{x}} \pm \mathrm{SD}\end{array}$ & t-value & $\mathrm{df}$ & $\mathrm{p}$ \\
\hline Pulp & 12 & $96.91 \pm 0.93$ & $93.85 \pm 1.21$ & 6.92 & 22 & $<0.01$ \\
\hline Connective tissue & 12 & $3.09 \pm 0.93$ & $6.15 \pm 1.22$ & -6.92 & 22 & $<0.01$ \\
\hline White pulp & 12 & $16.60 \pm 1.14$ & $6.04 \pm 1.31$ & 21.01 & 22 & $<0.01$ \\
\hline Red pulp & 12 & $60.04 \pm 2.79$ & $80.08 \pm 3.29$ & -16.06 & 22 & $<0.01$ \\
\hline PALS & 12 & $10.51 \pm 1.24$ & $3.93 \pm 0.70$ & 15.86 & 22 & $<0.01$ \\
\hline Lymph follicles & 12 & $6.09 \pm 0.82$ & $2.11 \pm 0.65$ & 13.03 & 22 & $<0.01$ \\
\hline Germinal centers & 12 & $1.11 \pm 0.23$ & $0.14 \pm 0.13$ & 12.14 & 22 & $<0.01$ \\
\hline Mantle zone & 12 & $4.98 \pm 0.63$ & $1.97 \pm 0.54$ & 12.38 & 22 & $<0.01$ \\
\hline Marginal zone & 12 & $20.20 \pm 1.92$ & $7.69 \pm 1.27$ & 18.76 & 22 & $<0.01$ \\
\hline
\end{tabular}

$\bar{x}$ - Mean value of variables; SD - standard deviation; df - degree of freedom 
By comparing the reactive changes of the structural components of the spleen after the application of the therapeutic equivalent doses of dexamethasone and MPA, the stereological analysis showed that the two drugs did not cause significant mutual difference in the volume density of the total parenchyma (pulp), connective tissue, PALO and marginal zone. However, when comparing the volume density of the remaining structural components of the splenic tissue, a significant difference of the reactive changes was registered. This comparison showed that the therapeutic dose of dexamethasone caused more pronounced reduction of the volume density of the lymph follicles (germinal centers and mantle zone) and a significant increase in the red pulp (Table 5).

Table 5

Comparison of the effects of therapeutic doses of dexamethasone and MPA

\begin{tabular}{|c|c|c|c|c|c|c|}
\hline $\begin{array}{l}\text { Volume density } \\
\left(\% / \mathrm{mm}^{3}\right)\end{array}$ & $\mathrm{n}$ & $\begin{array}{c}\operatorname{Dex}(0.6 \mathrm{mg} / \mathrm{kg} \mathrm{bw}) x \\
\pm \mathrm{SD}\end{array}$ & $\begin{array}{c}\text { MPA }(30 \mathrm{mg} / \mathrm{kg} \mathrm{bw}) \\
\bar{x} \pm \mathrm{SD}\end{array}$ & t-value & $\mathrm{df}$ & $\mathrm{p}$ \\
\hline Pulp & 12 & $94.20 \pm 0.90$ & $93.93 \pm 1.00$ & 0.70 & 22 & n.s. \\
\hline Connective tissue & 12 & $5.80 \pm 0.90$ & $6.07 \pm 1.00$ & -0.70 & 22 & n.s. \\
\hline White pulp & 12 & $5.21 \pm 1.09$ & $6.55 \pm 1.24$ & -2.81 & 22 & 0.01 \\
\hline Red pulp & 12 & $82.32 \pm 2.16$ & $79.69 \pm 2.43$ & 2.80 & 22 & 0.01 \\
\hline PALS & 12 & $4.36 \pm 0.86$ & $4.38 \pm 0.77$ & -0.05 & 22 & n.s. \\
\hline Lymph follicles & 12 & $0.85 \pm 0.48$ & $2.18 \pm 0.63$ & -5.78 & 22 & $<0.01$ \\
\hline Germinal centers & 12 & $0.04 \pm 0.06$ & $0.19 \pm 0.12$ & -3.62 & 22 & $<0.01$ \\
\hline Mantle zone & 12 & $0.81 \pm 0.43$ & $1.99 \pm 0.53$ & -5.88 & 22 & $<0.01$ \\
\hline Marginal zone & 12 & $6.67 \pm 1.01$ & $7.66 \pm 1.51$ & -1.88 & 22 & n.s. \\
\hline
\end{tabular}

A comparison of the effects of the maximal therapeutic dose of dexamethasone and the maximal therapeutic dose of MPA showed that the two drugs did not cause significant mutual difference in the volume density of the total parenchyma (pulp) and the connective tissue. However, the maximal therapeutic dose of de-

xamethasone provoked significantly stronger suppressive effect on all structural components of the white pulp and the marginal zone. Significant reduction in these two cell compartments resulted in an increased volume density of the spleen red pulp (Table 6).

Table 6

Comparison of the effects of maximal therapeutic doses of dexamethasone and MPA

\begin{tabular}{|c|c|c|c|c|c|c|}
\hline $\begin{array}{c}\text { Volume density } \\
\left(\% / \mathrm{mm}^{3}\right)\end{array}$ & $\mathrm{n}$ & \begin{tabular}{c} 
Dex $\left(\frac{3}{\bar{x} \pm \mathrm{mg} / \mathrm{kg} \text { bw })}\right.$ \\
\hline Pulp
\end{tabular} & $\begin{array}{c}\text { MPA }\left(\frac{150 \mathrm{mg} / \mathrm{kg} \text { bw })}{\bar{x} \pm \mathrm{SD}}\right. \\
\text { t-value }\end{array}$ & $\mathrm{df}$ & $\mathrm{p}$ \\
\hline Connective tissue & 12 & $94.06 \pm 1.27$ & $93.85 \pm 1.21$ & 0.41 & 22 & n.s. \\
\hline White pulp & 12 & $1.85 \pm 0.52$ & $6.15 \pm 1.21$ & -0.41 & 22 & n.s. \\
\hline Red pulp & 12 & $89.61 \pm 2.55$ & $6.04 \pm 1.31$ & -10.3 & 22 & $<0.01$ \\
\hline PALS & 12 & $1.54 \pm 0.43$ & $80.08 \pm 3.29$ & 7.91 & 22 & $<0.01$ \\
\hline Lymph follicles & 12 & $0.30 \pm 0.23$ & $3.93 \pm 0.70$ & -9.94 & 22 & $<0.01$ \\
\hline Germinal centers & 12 & $0.00 \pm 0.00$ & $2.11 \pm 0.65$ & -8.98 & 22 & $<0.01$ \\
\hline Mantle zone & 12 & $0.30 \pm 0.23$ & $0.14 \pm 0.13$ & -3.48 & 22 & $<0.01$ \\
\hline Marginal zone & 12 & $2.61 \pm 1.30$ & $1.97 \pm 0.54$ & -9.72 & 22 & $<0.01$ \\
\hline
\end{tabular}

$\bar{x}$ - Mean value of variables; SD - standard deviation; df - degree of freedom

\section{Discussion}

The histological analysis of the spleen is particularly important because it gives insight to the presence of the spleen structural compo- nents that make the cell potential on which depends its defensive function. The normal spleen structure and the normal presence of the different tissue spleen compartments indicate nor- 
mal functional condition of this immune organ. The proliferative processes and the increase of the lymphocytes cell potential, with the emergence of active lymph follicles that possess germinal centers, correlated with the increase in the defense capabilities and suggest stimulation of the immune system. Conversely, the atrophic spleen processes suggest reducing its cellular defense potential, which means the occurrence of condition of immunosuppression.

The results of our study showed that a crucial change in the spleen structure after the administration of dexamethasone is an outstanding reduction of the functional lymphocyte cell potential, that is, in terms of immunosuppression. These present findings are consistent with numerous studies that confirm the immunosuppressive activity of dexamethasone $[2,4$, 10-13, 27].

The histological analysis of the spleen in the groups of rats treated with MPA showed that the structural changes in the spleen tissue caused by MPA were almost identical to those caused by the administration of dexamethasone. The only difference was that dexamethasone caused a more pronounced structural changes in the spleen tissue. This fact was particularly evident comparing the presence of germinal centers in the lymphoid follicles which showed that only dexamethasone administered at maximal therapeutic dose completely suppress the appearance of the germinal centers. However, the dominant change in the spleen morphology caused by MPA was aimed at reducing the lymphocyte cell potential or immunomodulation in terms of immunosuppression.

Very similar to our findings were published after the MPA administration in rabbits. The results demonstrated that MPA caused depletion of the lymphoid splenic tissue. This phenomenon, induced by corticoid action, supported the immunosuppressive properties of the drug, which prolonged the survival of some allografts and lowered the antibody response to different antigens [28].

Reducing the lymphocyte density and the reduction in the white pulp volume density may be due to the lymphocyte arrest, because one of the main features of the steroid hormones is their ability to inhibit the proliferative response of lymphocytes after exposure to mitogenic substances $[8,27,29]$.

The first data about the effect of MPA on the lymphocyte proliferative response to mitogenic substances showed that MPA has a significant inhibitory effect only when used in a proper concentration [30].

The quantification of the inhibitory effects was performed by determining the percentage of reduction of the thymidine incorporation into DNA in the peripheral blood lymphocytes of the rams. Comparing the effects of progestins shows that the greatest reduction causes 17- hydroxyprogesterone $(-59 \%$, i.e. reduced by $59 \%$ compared with the vehicle control, $100 \%$ ), while MPA reduces thymidine incorporation into DNA approximately $-24 \%$ [31]. However, some studies suggest that MPA severely reduces the proliferative response of the peripheral blood lymphocytes depending on the amount of the dose [11, 32-34].

The MPA ability to inhibit the proliferative activity of the immunocompetent cells suggests that MPA can interfere with normal mitotic cell division. It is thought that the inhibition of cell growth caused by MPA may be due to its power to prolong the G-2 phase of the mitotic cell cycle [35]. Also, the antimitotic activity was accompanied via significant inhibition of the occurrence of giant cell formation when incubating peripheral blood monocytes from the patients with breast cancer [36].

Apart from the fact that the reason for the reduced white pulp volume density and the reduced lymphocyte density can be lymphocyte arrest, this phenomenon could also be due to the activation and acceleration of apoptosis of the immunocompetent cells [37-39].

Glucocorticosteroids (including dexamethasone) as inducers of apoptosis have been published in numerous scientific studies that have studied the mechanisms by which glucocorticoids can induce programmed cell death. These mechanisms are analyzed in proliferating and non-proliferating thymocytes. Common to the different pathways of the apoptotic process is the binding of the glucocorticoid receptor and the corresponding modification of the expression of specific genes [3, 10-13, 38]. However, it is important that all steroids having glucocorticoid properties do not have the ability to 
perform the induction of the DNA fragmentation in apoptosis characteristic way [40].

Our results showed that the morphological features of the lymphoid tissue after application of MPA are almost identical to those after the application of dexamethasone. In both cases, a decrease in the density of lymphocytes and a lymphocyte depletion phenomenon were registered, without the presence of ambient inflammatory response that is characteristic for cells dying by apoptosis [41-43]. Therefore, this finding suggests that MPA may conduct remodeling of the lymphoid organs by apoptosis.

Most physiological and histological studies confirmed glucocorticoid activity of the MPA, that is, the MPA treatment resulted in increased plasma FSH concentration, increased IGF-1 secretion, and suppressed hypothalamicpituitary-adrenal axis and reduction of the thickness of the zona fasciculata and reticularis of the adrenal cortex $[5,6,14,44]$.

Previous morphological studies performed on Wistar rats showed that the intramuscularly dexamethasone treatment caused a significant decrease in the volume density of the thymic parenchyma, and especially sensitive substrate for the action of dexamethasone was the cortex of the thymus [4]. The structural changes observed in the thymus after the intramuscularly administration of MPA showed almost identical histological changes observed after the dexamethasone treatment [4, 18].

Also, it was recognized that the contraceptive depot MPA causes selective glucocorticoid activity and can alter the expression of the glucocorticoid receptor regulated genes. The investigation of the contraceptive doses of the depot MPA in two different murine Mycobacterium tuberculosis models altered the serum cytokine levels of the tumor necrosis factor- $\alpha$, granulocyte colony-stimulating factor and interleukin 10. Also, the depot MPA altered granulocyte-macrophage colony-stimulating factor and the monocyte chemotactic protein 1. All the above alterations in mice led to higher bacterial load in their lungs [19].

Studies on the effects of MPA in humans infected with Mycobacterium tuberculosis showed that MPA exhibits glucocorticoid action and the ability to suppress the immune response [45]. Therefore, it was assumed that pharmacological doses of MPA, used for endocrine therapy could have significant immunomodulatory effects.

The experimental studies conducted on rabbits showed that in the thymus, dexamethasone led to marked reduction of the relative and absolute numbers of $\mathrm{CD} 4(+) \mathrm{CD} 8(+)$ thymocytes [10]. To identify which cell types MPA might act on in order to modulate the autoimmune responses, the activation of spleen leukocytes was examined. Although the results of these trials showed a tendency to decreased numbers of spleen myeloid dendritic cells, plasmocytoid dendritic cells, $\mathrm{T}$ cells and $\mathrm{B}$ cells, the changes were not statistically significant. However, B cells showed significantly higher expression of CD40, a molecule important for B cell isotype class switching and germinal center formation. Unlike the finding with dendritic cells, there was no difference between the treatment groups in B cell expression of CD86. The final conclusion was that there were no differences in the expression of the activation marker CD69 on either CD4+ or CD8+ spleen $\mathrm{T}$ cells. These data tend toward the MPA ability to modulate the autoimmune responses in part through its effects on dendritic cells and suggest that high doses of depot-MPA have immunosuppressive effects [46].

Our results tend towards all previously discussed findings, because they clearly indicate that MPA exhibits immunosuppressive effect on the spleen tissue.

Contrary to all previously mentioned facts, there are still scientific papers that are contradictory to the previously described findings and views. However, it should be noted that most authors are convinced of the glucocorticoids and the immunosuppressive activity of MPA [5-7, 14, 28, 31, 47-49] against those who support the opposing option [50-52].

\section{Conclusion}

The results obtained in this investigation have shown that 7-day administration of medroxyprogesterone acetate (at a therapeutic dose of $30 \mathrm{mg} / \mathrm{kg}$ bw or maximal therapeutic dose of $150 \mathrm{mg} / \mathrm{kg} \mathrm{bw}$ ) provoked significant reduction of the volume density of all structural components of the white pulp and the marginal zone. These changes suggested atrophy of the spleen 
lymphoid tissue. Although the atrophic changes of the spleen were significant after application of both dexamethasone and medroxyprogesterone acetate the white pulp was significantly more sensitive substrate for dexamethasone than for MPA.

\section{REFERENCES}

1. Chung HT, Samlowski WE, Daynes RA. Modification of the murine immune system by glucocorticoids: alterations of the tissue localization properties of circulating lymphocytes. Cellular immunology. 1986; 101: 571-585.

2. Van Vliet E, Melis M, van Evijk W. The influence of dexamethasone treatment on the lymphoid and stromal composition of the mouse thymus: a flowcytometric and immunohistological analysis. Cellular Immunology. 1986; 103: 229-240.

3. Wyllie AH, Morris RG. Hormone-induced cell death. Purification and properties of thymocytes undergoing apoptosis after glucocorticoid treatment. Am J Pathol. 1982; 109: 78-87.

4. Mitevska E, Kostovska N, Vasilevska K, Trajkov D. Stereological study of thymus after dexamethasone application. Maced Pharm Bull. 2004; 50(2): 25-28.

5. Mitevska E, Spiroski M. Qualitative histological analysis of adrenal cortex following application of medroxyprogesterone acetate. Maced J Med Sci. 2010; 3(2): 123-131.

6. Mitevska E, Spiroski M. Quantitative analysis of adrenal cortical histological alterations after application of medroxyprogesterone acetate. Maced J Med Sci. 2010; 3(4): 352-357.

7. Staples LD, Binns RM, Heap RB. Influence of certain steroids on lymphocyte transformation in sheep and goats studied in vitro. J Endocrinol. 1983; 98(1): 55-69.

8. Golikov PP, Bobkova AS. Effect of steroid hormones on DNA matrix activity and glucocorticoidreceptor interaction. Probl Endocrinol. 1981; 27(3): 52-6.

9. Maule AG, Schreck CB. Glucocorticoid receptors in leukocytes and gill of juvenile coho salmon (Oncorhynchus kisutch). Gen Comp Endocrinol. 1990; 77(3): 448-55.

10. Jeklova E, Leva L, Jaglic Z, Faldyna M. Dexamethasone-induced immunosuppression: a rabbit model. Veterinary Immunology and Immunopathology. 2008; 122(3-4): 231-240.

11. Marchetti MC, Di Marco B, Cifone G, Migliorati G, Riccardi C. Dexamethasone-induced apoptosis of thymocytes: role of glucocorticoid receptor-associated Src kinase and caspase-8 activation. Blood. 2003; 101(2): 585-93.

12. Marchetti MC, Marco BD, Santini MC, Bartoli A, Delfino DV, Riccardi C. Dexamethasone-induced thymocytes apoptosis requires glucocorticoid recaptor nuclear translocation but not mitochondrial mem- brane potential transition. Toxicology letters. 2003; 139: 175-180.

13. Cifone MG, Migliorati G, Parroni R, Marchetti C, Millimaggi D, Santoni A, Riccardi C. Dexamethasone-induced thymocyte apoptosis: apoptotic signal involves the sequential activation of phosphorinositide-specific phospholipase $\mathrm{C}$, acidic sphingomyelinase, and caspases. Blood. 1999; 93(7): 2282-96.

14. Selman PJ, van Garderen E, Mol JA, van den Ingh TS. Comparison of the histological changes in the dog after treatment with the progestins medroxyprogesterone acetate and proligestone. Vet Q. 1995; 17(4): 128-33.

15. Kosaka A, Yamashita A. Experimental study of combination medical endocrine therapy on DMBAinduced mammary tumor, with special reference to the effect of drug-dose on various factors. Gan To Kagaku Ryoho. 1992; 19(1): 75-81.

16. Mitevska SE, Gerasimovska AZ, Kakaseva SL, Trajkov KD, Jurhar RM, Stojoska EP, Spiroski ZM. Histophisiology of the spleen after application of medroxyprogesterone acetate. Zbornik matice srpske za prirodne nauke / Proceedings for Natural Sciences, Matica Srpska. 1998; 95: 25-32.

17. Mitevska E, Spiroski M. Histological characteristics of mesenteric lymph nodes after application of medroxyprogesterone acetate. Makedonski medicinski pregled. 1998; 52(1-2): 3-7.

18. Mitevska E. Histological characteristics of thymus assessed with stereological parameters after medroxyprogesterone acetate application. Maced J Med Sci. 2011; 4(4): 367-371.

19. Kleynhans L, Du Plessis N, Allie N, Jacobs M, Kidd M, Van Helden P, et al. The Contraceptive Depot Medroxyprogesterone Acetate Impairs Mycobacterial Control and Inhibits Cytokine Secretion in Mice Infected with Mycobacterium tuberculosis. Infect Immun. 2013; 81(4): 1234-1244.

20. Baker HJ, Lindsey JR, WeisbrothSH, The Laboratory Rat. Research Applications, Academic Press 1980; USA.

21. Hebel R, Stromberg MW. Anatomy and Embryology of the Laboratory Rat, BioMed Verlag 1986; Germany.

22. Muss HB, Case LD, Atkins JN, Bearden JD $3^{\text {rd }}$, Cooper MR, Cruz JM, et al. Tamoxifen versus highdose oral medroxyprogesterone acetate as initial endocrine therapy for patients with metastatic breast cancer. Journal of Clinical Oncology. 1994; 12(8): 1630-1638.

23. Pronin VN, Pukhlikov AV. Characteristics of the surgical stage in the combined treatment of poorly differentiated cancer of the corpus uteri. Vopr Oncol. 1988; 34(9): 1102-1105.

24. Senga O, Miyakawa M, Hikita H, Horigome N, Kouzu $\mathrm{S}$, Kuwae K, et al. A case of complete response of breast cancer with pulmonary metastases to combination therapy of 5 DFUR and MPA. Gan To Kagaku Ryoho. 1994; 21(15): 2655-2658. 
25. Gudovic R, Matavulj M, Stefanovic N, LozanovCvetkovic Z. Osnovi stereologije. Folia anatomica. 1994; 21/22(2): 13 .

26. Kalisnik M Temelji stereologije. Acta Stereologica 1985; 4(1): 1-148.

27. Bianchini R, Nocentini G, Krausz LT, Fettucciari K, Coaccioli S, Ronchetti S, Riccardi C. Modulation of Pro- and Antiapoptotic Molecules in Double-Positive $\left(\mathrm{CD}^{+} \mathrm{CD}^{+}\right)$Thymocytes following Dexamethasone Treatment. JPET. 2006; 319(2): 887-897.

28. Catalano G, Altomare D, Laurentaci G. Immunodepressive action and effects of medroxyprogesterone acetate on the lymphatic tissue of the spleen of rabbits. Arch Sci Med. 1982; 139(3): 269-278.

29. Rondinone CM, Schillaci R, Castillo MB, roldan A. Inhibitory effect of $11 \beta$-hydroxypregna-1,4-diene3,20-dione (delta HOP) on lymphocyte proliferation. Clin Exp Imunol. 1991; 86(2): 311-314.

30. Corsini G, Puppo F. Effect of medroxyprogesterone acetate upon PHA, Con A and PWM stimulated lymphocytes and on E-rosette function. J Immunopharmacol. 1982-1983; 4(3):247-253.

31. Staples LD, Heap RB, Brown D, Marrs RW. Structural requirements for steroid inhibition of sheep lymphocyte mitogenesis in vitro. Steroids. 1984; 44(5): 419-433.

32. Malarkey WB, Burleson Cacioppo JT, Poehlmann K, Glaser R, Kiecolt-Glaser JK. Differential effects of estrogen and medroxyprogesterone on basal and stress-induced growth hormone release, IGF-1 levels, and cellular immunity in postmenopausal women. Endocrine. 1997; 7(2): 227-233.

33. Mantovani G, Maccio A, Esu S, Lai P, Santona MC, Massa E, et al. Medroxyprogesterone acetate reduces the in vitro production of cytokines and serotonin involved in anorexia/cachexia and emesis by peripheral blood mononuclear cells of cancer patients. Eur J Cancer. 1997; 33(4): 602-607.

34. Scambia G, Panici PB, Maccio A, Castelli P, Serri F, Mantovani G, et al. Effects of antiestrogen and progestin on immune functions in breast cancer patients. Cancer. 1988; 61(11): 2214-2218.

35. Huber H, Huslein P, Muchalica W, Wagenbichler P. radiosensitising effect of medroxyprogesterone acetate on endometrial cancer cells in vitro. Cancer. 1984; 54: 999-1001.

36. Al-Sumidaie AM. The effect of tamoxifen and medroxyprogesterone on giant cell formation by monocytes from patients with breast cancer. J Cancer Res Clin Oncol. 1988; 114(4): 399-404.

37. Coldham NG, Lai LC, Ghilchik MW, Walker MM, James VH, Reed MJ. The effect of treatment with 4hydroxyandrostenedione or medroxyprogesterone acetate on human breast tumour regression. Anticancer Research. 1993; 13(3): 753-758.

38. King KL, Cidlovski JA. Cell cycle regulation and apoptosis. Annu Rev Physiol. 1998; 60: 601-617.

39. Zieger G, Zieger W, Kubatsch B. Effect and duration of gestagen influence on adrenal cortex and ovary. A morphological study in the Syrian golden hamster. Pathol Res Pract. 1982; 173(3): 202-217.
40. Vicent GP, Pecci A, Ghini AA, Piwien-Pilipuk G, Valeiro AS, Burton G, et al. The glucocorticoid properties of the synthetic steroid pregna-1,4-diene11 beta-ol-3,20-dione (delta-HOP) are not entirely correlated with the steroid binding to the glucocorticoid receptor. Mol Cell Endocrinol. 1999; 149(12): 207-219.

41. Henson PM, Bratton DL. Antiinflamatory effects of apoptotic cells. J Clin Invest. 2013; 123(7): 2773-2774.

42. Freire-de-Lima CG, Yi Qun Xiao, Gardai SJ, Bratton DL, Schiemann WP, Henson PM. Apoptotic cells, through transforming growth factor- $\beta$, co-ordinately induce anti-inflammatory and suppress pro-inflammatory eicosanoid and NO synthesis in murine macrophages. Journal of Biological Chemistry. 2006; 281: 38376-38384.

43. Gao Y, Herndon JM, Zhang H, Griffith TS, Ferguson TA. Antiinflammatory effects of CD95 ligand (FasL)-induced apoptosis. JEM. 1998; 188(5): 887.

44. Beijerink NJ, Bhatti SFM, Okkens AC, et al. Adenohypophiseal function in bitches treated with medroxyprogesterone acetate. Dom Anim Endocrinol. 2007; 32: 63-78.

45. Kleynhans L, Du Plessis N, Black GF, Loxton AG, Kidd M, Van Helden PD, et al. Medroxyprogesterone Acetate Alters Mycobacterium Bovis BCGInduced Cytokine Production in Peripheral Blood Mononuclear Cells of Contraceptive Users. PLoS One 2011; 6(9): e24639.

doi:10.1371/journal.pone.0024639.

46. Hughes GC, Martin D, Zhang K, Hudkins KL, Alpers CE, Clark EA, Elkon KB. Decrease in glomerulonephritis and Th1-associated autoantibody production after progesterone treatment in NZB/NZW Mice. Arthritis \& Rheumatism. 2009; 60(6): 17751784.

47. Selman PJ, Mol JA, Rutteman GR, Rijnberk A. Progestin treatment in the dog. II. Effects on the hypothalamic-pituitary-adrenocortical axis. European Journal of Endocrinology. 1994; 131(4): 422-430.

48. Fenton SL, Luong QT, Sarafeim A, Mustard KJ, Pound J, Desmond JC, et al. Fibrates and medroxyprogesterone acetate induce apoptosis of primary Burkitt's lymphoma cells and cell lines: potential for applying old drugs to a new disease. Leukemia. 2003; 17(3): 568-575.

49. Tomasicchio M, Avenant C, Du Toit A, Ray RM, Hapgood JP. The progestin-only contraceptive medroxyprogesterone acetate, but not norethisterone acetate, enhances HIV-1 Vpr-mediated apoptosis in human CD4+ T cells through the glucocorticoid receptor. PLoS One 2013; 8(5):e62895. doi: 10.1371 /journal pone.0062895.

50. Bakry S, Ahmed HA, Al-OtaibiPrenatal ML. Exposure to medroxyprogesterone acetate. AmericanEurasian Journal of Toxicological Sciences. 2010; 2(1): 01-12.

51. Vermeulen M, Pazos P, Lanari C, Molinolo A, Gamberale R, Geffner JR, Giordano M. Medroxypro- 
gesterone acetate enhances in vivo and in vitro antibody production. Immunology. 2001; 104(1): 80-86.

52. Ory K, Lebeau J, Levalous C, Bishay, Fouchet P, Allemand I, et al. Apoptosis inhibition mediated by medroxyprogesterone acetate treatment of breast cancer cell lines. Breast cancer Res Treat. 2001; 68(3): 187-198

Р е $з$ и м е

ПРОМЕНИ НА СЛЕЗИНАТА

КАЈ СТАОРЦИ ВИСТАР ТРЕТИРАНИ СО ДЕКСАМЕТАЗОН

И МЕДРОКСИПРОГЕСТЕРОН АЦЕТАТ ЕВАЛУИРАНИ СО СТЕРЕОЛОШКИ ПАРАМЕТРИ

\section{Елида Митевска, \\ Ирена Костадинова-Петрова, Невена Костовска}

Институт за медицинска, експериментална и применета хистологија и ембриологија, Медицински факултет, Универзитет „Св. Кирил и Методиј“, Скопје, Р. Македонија

Целта на нашето истражување беше да се процени имуносупресивниот ефект на медроксипрогестерон ацетатот (МПА) преку одредување на волуменската густина на структурните компоненти на слезината. Исто така, волуменските густини на истите структурни компоненти на слезината беа одредени и по администрација на дексаметазон, со цел да се процени дали морфолошките промени предизвикани од МПА се во иста насока со промените предизвикани од дексаметазонот.
Во пет групи беа поделени 60 женски стаорци вистар. Контролната група стаорци примаше физиолошки раствор. Останатите четири експериментални групи примаа: дексаметазон во терапевтска дневна доза од $0.6 \mathrm{mg} / \mathrm{kg}$ тт и максимална терапевтска доза од $3 \mathrm{mg} / \mathrm{kg}$ тт, и МПА во терапевтска доза од $30 \mathrm{mg} / \mathrm{kg}$ тт и максимална терапевтска доза од $150 \mathrm{mg} / \mathrm{kg}$ тт. Медикаментите беа аплицирани интрамускулно во тек на седум дена. Стереолошките мерења беа извршени со употреба на Weibl-ов мултинаменски тест-систем (М-42).

Хистолошката анализа на структурните компоненти на слезината кај стаорците третирани со дексаметазон и МПА покажаа редукција на белата пулпа и маргиналната зона и видлив пад на клеточната густина на лимфоцитната компонента на пулпата. Стереолошката анализа на слезината покажа значајно намалување на волуменската густина на нејзината пулпа и значајно зголемување на волуменската густина на сврзното ткиво. Намалената застапеност на пулпата на слезината се должеше, главно, на намалувањето на волуменската густина на сите структурни компоненти од белата пулпа. Промените беа регистрирани кај сите медикаментозно третирани групи стаорци.

Нашите резултати покажаа дека МПА предизвикува промени што сугерираат атрофија на лимфоидното ткиво на слезината. Иако атрофичните промени на слезината беа значајни по апликација и на дексаметазон и на МПА, белата пулпа беше значајно посензитивен супстрат за дексаметазон отколку за МПА.

Клучни зборови: слезина, стаорци вистар, стереолошка анализа, дексаметазон, медроксипрогестерон ацетат. 